\title{
Structural Evaluation and Antibacterial Sensitivity of Iron (III) Complexes of 4-n-hexyloxybenzoylhydrazine with Some Aliphatic and Aromatic Aldehydes
}

\author{
M. Al-Amin-Al-Azadul Islam*, M. A. Mumit, T. K. Pal, and M. A. Alam
}

Department of Chemistry, Rajshahi University of Engineering \& Technology, Rajshahi-6204, Bangladesh

Received 11 February 2012, accepted in final revised form 8 July 2012

\begin{abstract}
The condensation reaction of $N$-alkylidene or $N$-arylidene-(4- $n$-hexyloxy)benzoylhydrazone [L] (1-7) where, $\mathrm{R}$ = formaldehyde (1), acetaldehyde (2), butyraldehyde (3), cinnamaldehyde (4), 4-N,N-dimethylaminobenzaldehyde (5), 2-hydroxybenzaldehyde (6) and 4methoxybenzaldehyde (7) with Fe(III) chloride hexahydrate afforded octahedral (8-9) $\left[\mathrm{Fe}\left(\mathrm{L}_{3}\right) \cdot \mathrm{nH}_{2} \mathrm{O}\right]$ and square-pyramidal (10-14) $\left[\mathrm{Fe}\left(\mathrm{L}_{2}\right) \mathrm{Cl} \cdot \mathrm{nH}_{2} \mathrm{O}\right]$ complexes. The complexes (8-10) were obtained in presence of pyridine and the complexes (11-14) were obtained by the direct reaction of the Schiff's bases with $\mathrm{Fe}^{3+}$ ion. The complexes were characterized by magnetic moment measurement, UV-visible, infrared, ${ }^{1} \mathrm{H}-\mathrm{NMR}$ and TGA (Thermo gravimetric analysis) studies. The Schiff's bases containing small alkyl group at the hydrazine moiety formed octahedral complexes, while the bulky/aryl/substituted aryl moiety, yielded five coordinated square-pyramidal complexes. The complexes were found to be quite stable and decomposition of the complexes ended with ferric oxide as final product. Complexes (10) and (13) showed no activity against all the bacteria. Complexes (8), (9) and (12) showed resistance while the complex (14) manifested intermediate antibacterial activity.
\end{abstract}

Keywords: 4-n-hexyloxybenzoylhydrazine; Thermogravimetric analyses ; Antibacterial activity; Aroylhydrazones.

(C) 2012 JSR Publications. ISSN: 2070-0237 (Print); 2070-0245 (Online). All rights reserved.

doi: http://dx.doi.org/10.3329/jsr.v4i3.9807 J. Sci. Res. 4 (3), 635-64 (2012)

\section{Introduction}

Iron is the most abundant transition element and serves more biological roles than any other metal. It can therefore serve to illustrate the possibilities available for the absorption, storage, handling and use of an essential metal. Among the most important biological activities of iron in living organism is the transport of oxygen through hemoglobin, in which a porphyrin ring is chelated to an iron atom. The porphyrin ring

${ }^{*}$ Corresponding author: aamin_ruet@yahoo.com 
consists of a macrocyclic pyrrole system with conjugated double bonds and various groups attached to the perimeter. The heme group is a porphyrin ring with an iron atom at the center. The oxidation state of the iron may be either +2 or +3 and the importance of the cytochromes lie in their ability to act as redox intermediates in electron transfer. Schiff's bases are able to stabilize various metal ions in different oxidation states and thereby control the performance of metals in a large variety of useful catalytic transformations. A variety of enzymes are able to catalyze different reactions such as oxidation, reduction and isomerization containing iron bound to porphyrin [1, 2]. Several non-heme iron (III) complexes with mixed nitrogen sulfur coordination sphere have been reported [3-6]. One of the main objectives of their synthesis was to build chemical models of iron containing nitrile hydratases. These enzymes catalyze the hydration of nitriles to amides, are the first non-heme iron enzymes with a low-spin iron (III) active site. Some diaroylhydrazine ligands were found to exhibit significantly greater Fe chelation efficacy than desferrioxamine [7]. These ligands are considered as orally effective drugs for the treatment of iron overload disorders in improving the health of patients suffering diseases such as $\beta$-thalassemia. Some of the above chelators effectively mobilize Fe from prelabeled cells and prevent Fe uptake from transferrin by the cell in addition to exhibit low cytotoxicity. Moreover, aroylhydrazinato iron(III) complexes play and important role in exhibiting antimicrobial activities as well as in the determination of metal ions in various environmental matrices [8]. As a continued interest in this area, the present work was aimed to prepare several $\mathrm{N}$-alky/aryl substituted aroylhydrazones and to investigate into their antibacterial activities.

\section{Experimental}

\subsection{Physical measurements}

IR spectra (4000-400 $\mathrm{cm}^{-1}$ ) were taken as KBr disc using a NICOLET 380 FTIR spectrophotometer (Belgium). ${ }^{1} \mathrm{H}$ NMR spectra were recorded on a Brucker UltraShield ${ }^{\mathrm{TM}} 400$ spectrometer (Shimadzu, Japan) in $\mathrm{CDCl}_{3}$ and $\mathrm{d}_{6}$-DMSO using tetra methyl silane (TMS) as internal standard. Magnetic measurements were carried out on a magnetic susceptibility balance (Sherwood Scientific, UK). Molar conductance was determined on a heavy-duty conductivity/temperature meter, Extech Instruments (USA), model No. 407303. The UV-visible spectra were scanned on a T60U spectrophotometer (200-800 nm) using $10^{-5} \mathrm{M}$ solution (DMSO). Thermogravimetric analyses (TGA) were carried out in the temperature range between $25^{\circ} \mathrm{C}$ to $600^{\circ} \mathrm{C}$ under nitrogen atmosphere by using TGA Q50 V6.4 Instrument (Belgium). Approximately 5-8 mg sample was weighed out in aluminium crucible and heated at the rate of $10^{\circ} \mathrm{C} / \mathrm{min}$. The data were recorded using a platinum crucible as standard, the plot obtained as derivative weight changes $\left(\% /{ }^{\circ} \mathrm{C}\right)$ as a function of time. 


\subsection{Materials and methods}

Ethyl-4-hydroxybenzoate, hydrazine hydrate (99.99\%) and aldehydes were obtained from BDH chemicals (England), iron (III) chloride hexahydrate was obtained from Fluka Chemica (Switzerland). The solvents were purified by standard method [9]. The starting materials (ethyl-4- $n$-hexyloxybenzoate) and the ligand precursor (4- $n$ hexyloxybenzoyl hydrazine) were prepared by known procedure [10, 11].

\subsection{Antimicrobial assay}

Sixteen pathogenic bacteria viz., B. Sereus, B. Megaterium, B. Subtilis, S. Paratyphi, S. Tiphi, V. Parahemolyticus, V. Mimicus, S. Aureus, E. Coli, S. Dysenteriae, P. Aureus, S. Lutea, S. Boydii, S. Cerevaceae, C. Albicans and A. Niger were used to test the biological potential of the complexes. Antimicrobial activity was determined by modified disc diffusion method [12]. A lawn of microorganisms was prepared by pipetting and evenly spreading $10 \mu \mathrm{l}$ of inoculum, adjusted turbidometrically to $10^{5}-10^{6}$ $\mathrm{CFU} / \mathrm{cm}^{3}$ (CFU = colony forming units) onto agar set in Petri dishes, using nutrient agar (NA) for the bacteria. Whatman No. 1 filter paper discs of $5 \mathrm{~mm}$ diameter were impregnated with dimethyl sulphoxide stock solutions of the complexes. The stock solution was prepared by dissolving $8 \mathrm{mg}$ of each sample in $1 \mathrm{ml} \mathrm{DMSO}$. 50 $\mu \mathrm{l}$ of the stock solution was taken by using a micropipette to soak the discs and dried under sterile conditions. Dried dishes were then placed on previously inoculated agar surfaces. The plates were inverted and incubated for $24 \mathrm{~h}$ at $35 \pm 2^{\circ} \mathrm{C}$ for the bacteria. Antimicrobial activity was indicated by the presence of clear inhibition zones as diameter $(\mathrm{mm})$ around the discs. Kanamycin $(30 \mu \mathrm{g} /$ disc) was used as standard drug.

\subsection{Synthesis of Schiff's bases (1-7)}

The Schiff's bases were prepared in the same way as described in our previous article [11]. For example, the preparation of $N$-methylene-(4-n-hexyloxy)benzoylhydrazone (1) is as follows: formaldehyde solution (37\%) $(0.16 \mathrm{~g}, 2 \mathrm{mmol})$ was added to a solution of (4-n-hexyloxy) benzoylhydrazine ( $0.57 \mathrm{~g} 2 \mathrm{mmol}, 20 \mathrm{ml}$ ethanol) and the resulting mixture was refluxed for $1 \mathrm{~h}$ (checked by TLC). The ligand was isolated with the evaporation of solvent in vacuum line as it is highly soluble in ethanol and purified by column chromatography in dichloromethane and pet-ether $(2: 1 ; \mathrm{v} / \mathrm{v})$ as eluent. The ligand (2) was also obtained by the same procedure using acetaldehyde. The ligand (3) was obtained after reduction of volume into one-third using butyraldehyde. The ligands (4-7) were prepared by using cinnamaldehyde (4), 4- $N, N$-dimethylaminobenzaldehyde (5), 2-hydroxybenzaldehyde (6) and 4-methoxybenzaldehyde (7) respectively, under stirring for 15-30 min without further treatment. The white precipitate of each ligand was filtered off, washed with ethanol and pet-ether successively and dried in vacuum over anhydrous $\mathrm{CaCl}_{2}$. 


\subsection{Synthesis of complexes (8-14) [Tris- $\left\{N^{\prime}\right.$-(methylene)-(4-n-hexyloxy)
(8) benzoylhydrazinato- $\left.\kappa^{2}-N^{\prime}, O\right\}$ iron(III) (8)}

A mixture of (4-n-hexyloxy)benzoylhydrazine, (0.24g, $1 \mathrm{mmol}$ ) and 37\% formaldehyde solution (0.08g, $1 \mathrm{mmol})$ was refluxed in methanol $(15 \mathrm{ml})$ for $1 \mathrm{hr}$. Whence the Schiff's base was formed (checked by tlc), a solution of ferric chloride hexahydrate $(0.13 \mathrm{~g}, 0.5$ mmol) in methanol (5 ml) was added and reflux was continued for 16 hrs, which resulted a deep blue solution. A deep blue precipitate was obtained after the addition of $0.15 \mathrm{~g}$ of pyridine and subsequent cooling. The precipitate was filtered off, washed with hot methanol and dried in air. Complexes (9-10) were also prepared in the same procedure using acetaldehyde and butyraldehyde, respectively.

\section{[Chloro-bis $\left.\left\{\left(N^{\prime}-3-p h e n y l p r o p-2-e n y l-i d e n e\right)-(4-n-h e x y l o x y) b e n z o y l h y d r a z i n a t o-\kappa^{2} N^{\prime}, O\right\}\right]$ iron(III) (11)}

In a solution of 4-n-hexyloxybenzoylhydrazine, (0.24 g, $1 \mathrm{mmol})$ in methanol (15 ml), cinnamaldehyde ( $0.13 \mathrm{~g}, 1 \mathrm{mmol}$ ) was added with constant stirring. After 5-10 min, a white precipitate was formed, which was dissolved by additional methanol $(10 \mathrm{ml})$ and subsequent reflux. A solution of ferric chloride hexahydrate $(0.13 \mathrm{~g}, 0.5 \mathrm{mmol})$ in methanol $(5 \mathrm{ml})$ was added to this solution and reflux was continued. A brown precipitate was formed after $10 \mathrm{~min}$. of reflux. The precipitate was separated, washed with hot methanol and dried in air. The product was further purified by washing with hot chloroform. The complexes (12)-(14) were also prepared by the same manner using 4-dimethylaminobenzaldehyde (12), 2hydroxybenzaldehyde (13) and 4-methoxybenzaldehyde (14) respectively. The complexes were also purified by washing with chloroform.

\section{Results and Discussion}

The Schiff's bases $\left[\mathrm{C}_{6} \mathrm{H}_{13} \mathrm{OC}_{6} \mathrm{H}_{4} \mathrm{C}(=\mathrm{O}) \mathrm{NHN}=\mathrm{CHR}\right](\mathbf{1 - 7})$ were prepared by the condensation of 4-n-hexyloxybenzoyl hydrazine, with different aliphatic and aromatic aldehydes such as formaldehyde (1), acetaldehyde (2), butyraldehyde (3), cinnamaldehyde (4), 4- N,Ndimethylaminobenzaldehyde (5), 2-hydroxybenzaldehyde (6) and 4-methoxybenzaldehyde (7) in 1:1 molar ratio as shown in scheme 1 . The ligands (1-3) were obtained under reflux and isolated by reduction in volume up to $1 / 3$ and subsequent cooling whereas the ligands (4-7) were obtained at room temperature under stirring for 15-30 min. This implies that the activity of aromatic aldehydes with 4-n-hexyloxybenzoylhydrazine is better than those of aliphatic aldehydes. The Schiff's bases (1-3) have reacted with ferric chloride in the presence of pyridine. This may be explained by the catalytic activity of pyridine, that facilitated the deprotonation of the Schiff's bases, as it does not coordinate with Fe(III) as reported earlier [13]. On the other hand, the Schiff's bases (4-7) had coordinated with ferric chloride under reflux in neutral medium (in the absence of pyridine). This observation also suggest that the formation of Fe(III) complexes with aroylhydrazones containing aromatic aldehyde moiety is faster than those with aliphatic aldehyde moiety. Most probably, the $\pi$-conjugating effect of phenyl ring plays an important role during coordination. The Schiff bases containing small 
aldehyde moiety such as formaldehyde (1) and acetaldehyde (2) coordinated with Fe(III) ion in a 3:1 (ligand: metal) molar ratio, while the other Schiff bases containing bulky substituents at the azomithine moiety (3-7) have coordinated in a 2:1 molar ratio, inasmuch as all the reactions were conducted in a 2:1 molar ratio. This why, the complexes (8) and (9) were obtained in lower yield. The room temperature molar conductance values (Table 1) in DMSO suggested the non-electrolytic nature of the complexes [14, 15].

Table 1. Physical properties of the investigated compounds.

\begin{tabular}{clccccc}
\hline Comp & \multicolumn{1}{c}{ Formula } & Color & $\begin{array}{c}\text { Yield } \\
\text { (\%) }\end{array}$ & M.p $\left({ }^{\circ} \mathrm{C}\right)$ & $\begin{array}{c}\mu_{\text {eff }} \\
(\mathrm{B} . \mathrm{M} .)\end{array}$ & $\Lambda_{m}(\mu \mathrm{S})$ \\
\hline $\mathbf{1}$ & $\mathrm{C}_{14} \mathrm{H}_{20} \mathrm{~N}_{2} \mathrm{O}_{2}$ & White & 87 & 49 & - & - \\
$\mathbf{2}$ & $\mathrm{C}_{15} \mathrm{H}_{22} \mathrm{~N}_{2} \mathrm{O}_{2}$ & White & 89 & 47 & - & - \\
$\mathbf{3}$ & $\mathrm{C}_{17} \mathrm{H}_{26} \mathrm{~N}_{2} \mathrm{O}_{2}$ & White & 91 & 45 & - & - \\
$\mathbf{4}$ & $\mathrm{C}_{22} \mathrm{H}_{26} \mathrm{~N}_{2} \mathrm{O}_{2}$ & White & 200 & 66 & - & - \\
$\mathbf{5}$ & $\mathrm{C}_{22} \mathrm{H}_{29} \mathrm{~N}_{3} \mathrm{O}_{2}$ & White & 193 & 43 & - & - \\
$\mathbf{6}$ & $\mathrm{C}_{20} \mathrm{H}_{24} \mathrm{~N}_{2} \mathrm{O}_{3}$ & White & 135 & 62 & - & - \\
$\mathbf{7}$ & $\mathrm{C}_{21} \mathrm{H}_{26} \mathrm{~N}_{2} \mathrm{O}_{3}$ & White & 142 & 54 & - & - \\
$\mathbf{8}$ & {$\left[\mathrm{Fe}(\mathrm{L})_{3}\right] .7 \mathrm{H}_{2} \mathrm{O}$} & Deep blue & 25 & 247 & 5.98 & 5.6 \\
$\mathbf{9}$ & {$\left[\mathrm{Fe}(\mathrm{L})_{3}\right] \cdot 5 \mathrm{H}_{2} \mathrm{O}$} & Deep blue & 29 & 242 & 5.91 & 7.1 \\
$\mathbf{1 0}$ & {$\left[\mathrm{Fe}(\mathrm{L})_{2} \mathrm{Cl}\right] .2 \mathrm{H}_{2} \mathrm{O}$} & Deep blue & 24 & 277 & 5.62 & 6.8 \\
$\mathbf{1 1}$ & {$\left[\mathrm{Fe}(\mathrm{L})_{2} \mathrm{Cl}\right] .3 \mathrm{H}_{2} \mathrm{O}$} & Brown & 50 & 237 & 5.46 & 12.7 \\
$\mathbf{1 2}$ & {$\left[\mathrm{Fe}(\mathrm{L})_{2} \mathrm{Cl}\right] .3 \mathrm{H}_{2} \mathrm{O}$} & Orange & 49 & 222 & 5.49 & 2.9 \\
$\mathbf{1 3}$ & {$\left[\mathrm{Fe}(\mathrm{L})_{2} \mathrm{Cl}\right] \mathrm{H}_{2} \mathrm{O}$} & Orange & 37 & 210 & 5.67 & 7.7 \\
$\mathbf{1 4}$ & {$\left[\mathrm{Fe}(\mathrm{L})_{2} \mathrm{Cl} \cdot \mathrm{H}_{2} \mathrm{O}\right] .3 \mathrm{H}_{2} \mathrm{O}$} & Greenish grey & 49 & 289 & 5.44 & 2.2 \\
\hline
\end{tabular}

\subsection{Infrared spectra}

The IR spectra of the Schiff bases were described elaborately in our previous article [11], For comparison, the IR data are included in Table 2. They showed a sharp medium intensity absorption in the region between $3286-3211 \mathrm{~cm}^{-1}$, a very strong band between 1649-1631 and a strong band between 1610-1607 $\mathrm{cm}^{-1}$, corresponding to the $v_{\mathrm{N}-\mathrm{H},} v_{\mathrm{C}=\mathrm{O}}$ and $v_{\mathrm{C}=\mathrm{N}}$ stretching vibrations respectively $[10,11]$. The ligands also exhibited a strong band at $\sim 1261-1251 \mathrm{~cm}^{-1}$ assignable to the $v_{\mathrm{C}-\mathrm{o}}$ (phenolate/ether) stretching vibration [16]. The ligands also showed a medium to strong band at $1055-1022 \mathrm{~cm}^{-1}$ (not shown in the table) for the $v_{\mathrm{N}-\mathrm{N}}$ stretching of the azine moiety. A medium to strong band at 1586-1541 cm $\mathrm{cm}^{-1}$ was suggested for the aromatic $v_{\mathrm{C}=\mathrm{C}}$ stretches [17]. The absence of $v_{\mathrm{N}-\mathrm{H}}$ and $v_{\mathrm{C}=\mathrm{O}}$ stretching bands in the IR spectra of the complexes (Table 2) 
suggested that coordination had taken place through the oxygen atom of the amide moiety by deprotonation of the amide proton via the enol form [10,13], i.e., [$\mathrm{C}(=\mathrm{O}) \mathrm{NH}-\mathrm{N}=\mathrm{CHR}] \rightarrow[-\mathrm{C}(-\mathrm{O})=\mathrm{N}-\mathrm{N}=\mathrm{CHR}]$. A strong band appeared at approx. 1606 $\mathrm{cm}^{-1}$ assigned to the $v_{\mathrm{C}=\mathrm{N}}$ stretching, which has shifted to the lower frequency (approx. 5 $\mathrm{cm}^{-1}$ ) than the corresponding ligands. This may be explained by a drift of the lone pair electron density of the azomithine nitrogen towards the iron atom $[10,13,18]$, which indicated the coordination through the azomithine nitrogen atom. The appearance of a broad band in the range of 3465-3427 $\mathrm{cm}^{-1}$ indicated the presence of $v_{\mathrm{O}-\mathrm{H}}$ of hydrated water molecule in the complexes [19, 20]. Fresh bands at 526-529 $\mathrm{cm}^{-1}$ and 507-495 $\mathrm{cm}^{-1}$ may be assigned to the $v(\mathrm{Fe}-\mathrm{N})$ and $v(\mathrm{Fe}-\mathrm{O})$ stretching modes, which also provided information for the formation of the complexes through the azomithine nitrogen and deprotonated amidic oxygen atoms respectively [10, 13, 19, 20]. Moreover, the complexes also exhibited various strong bands from 1588-1409 $\mathrm{cm}^{-1}$ and from 1264-1251 $\mathrm{cm}^{-1}$ assigned to the aromatic $v_{\mathrm{C}=\mathrm{C}}$ and ethereal $v_{\mathrm{C}-\mathrm{O}-\mathrm{C}}$ stretches respectively $[10,16,18]$.

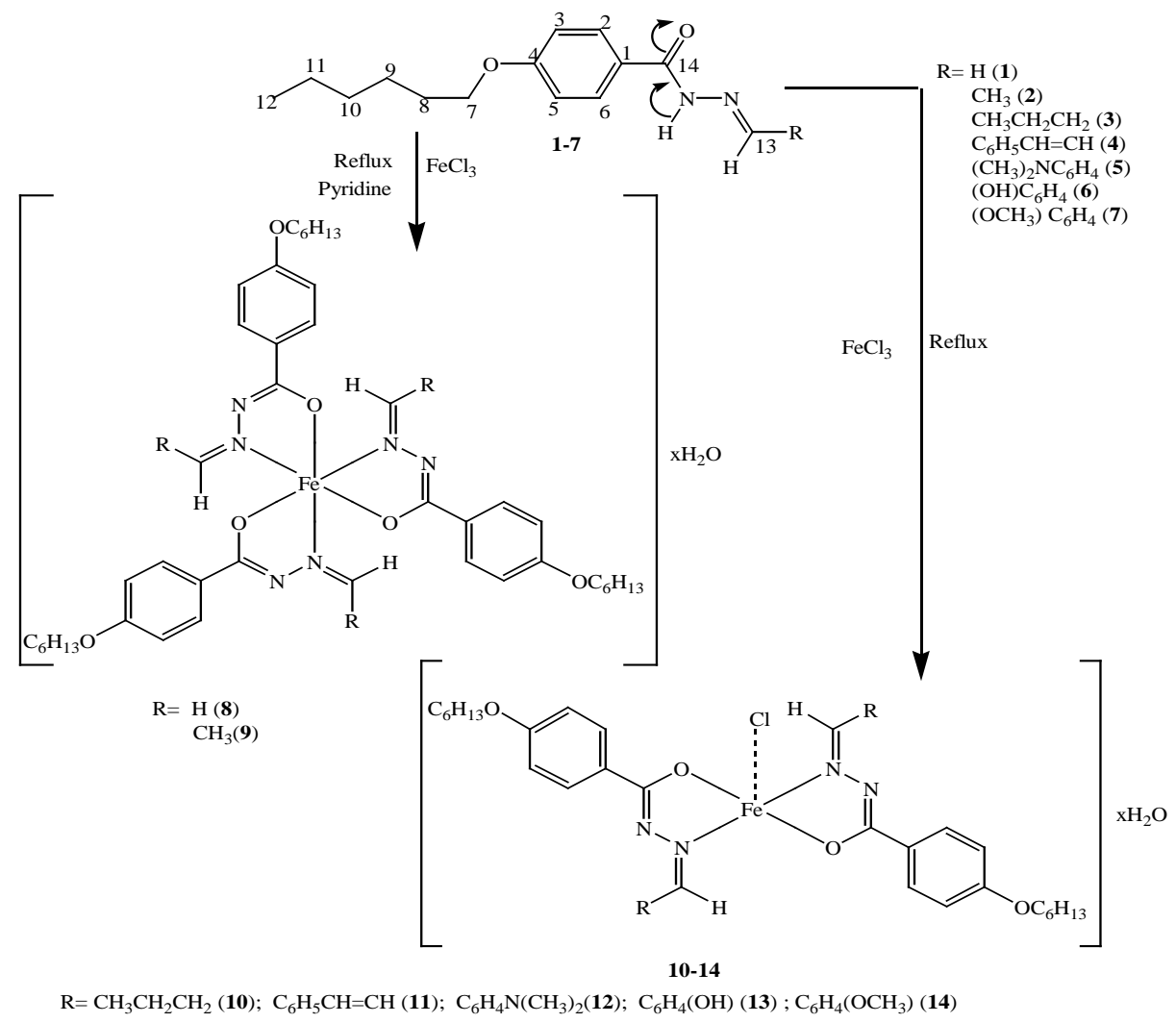

Scheme 1. General scheme for the preparation of the Schiff's bases (1-7) and their complexes. 


\section{2. ${ }^{1} \mathrm{H}-\mathrm{NMR}$ spectra}

Table 3 represents the ${ }^{1} \mathrm{H}-\mathrm{NMR}$ spectroscopic data of the Schiff's bases as also explained earlier [11]. The ligands showed multiplet bands at $\delta \sim 0.90\left(\mathrm{H}_{12}\right), 1.33$ $\left(\mathrm{H}_{11+10}\right), 1.45\left(\mathrm{H}_{9}\right), 1.78\left(\mathrm{H}_{8}\right)$ respectively (Scheme 1$)$ for the hexyl moiety $[10,11]$. The ligands also showed a triplet at $\delta$ 4.0-3.95 ppm for the $\mathrm{CH}_{2} \mathrm{O}$ protons $\left(\mathrm{H}_{7}\right)$ of the hexyl moiety. The ligands contained doublets at $\delta$ 7.98-7.68 and 6.93-6.81 ppm for the $\mathrm{H}_{2+6}$ and $\mathrm{H}_{3+5}$ protons of $-\mathrm{C}_{6} \mathrm{H}_{4}$ - aromatic ring. Both the $\mathrm{H}_{2+6}$ and $\mathrm{H}_{3+5}$ protons were shielded in case of saturated aldehydes due to the inductive effect of the alkyl group whereas these protons were deshielded in the ligands containing aromatic and conjugated aldehydes. The ligands exhibited two singlets at $\delta$ 8.41-7.52 and 9.92-8.99 corresponding to the azomithine $\left(\mathrm{H}_{13}\right)$ and amide $\left(\mathrm{H}_{14}\right)$ protons of $[-\mathrm{C}(=\mathrm{O}) \mathrm{NH}-\mathrm{N}=\mathrm{CHR}]$ moiety $[10,11]$. In ligand (3), the shift for the $-\mathrm{CH}_{2} \mathrm{CH}_{2} \mathrm{CH}_{3}$ group was overlapped with the hexyl moiety. The ligand (4), exhibited a triplet at $\delta 7.07$ for the $-\mathrm{CH}=\mathrm{CH}-\mathrm{Ph}$, a doublet at $\delta 6.74$ for the $-\mathrm{CH}=\mathrm{CH}-\mathrm{Ph}$ and a multiplet at 7.37-7.30 for the $-\mathrm{CH}=\mathrm{CH}-\underline{\mathrm{Ph}}$ protons respectively $[10,11]$. The ligand (5), displayed a singlet at $\delta 2.99$ for the $\mathrm{N}\left(\mathrm{CH}_{3}\right)_{2}$ and two doublets at $\delta 7.59$ and 6.65 for the $\mathrm{H}_{2^{\prime}+6^{\prime}}$ and $\mathrm{H}_{3^{\prime}+5^{\prime}}$ protons of the $\mathrm{C}_{6^{\prime}} \mathrm{H}_{4}{ }^{\prime} \mathrm{N}\left(\mathrm{CH}_{3}\right)_{2}$ moiety. The ligand (6), showed a multiplet band at $\delta$ 7.67-7.28 and a singlet at 11.16 for the phenyl $\left(\mathrm{C}_{6} \underline{\mathrm{H}}_{4}\right)$ and $-\mathrm{OH}$ protons respectively of the $-\mathrm{C}_{6^{\prime}} \mathrm{H}_{4^{\prime}}(\mathrm{OH})$ moiety. Similarly ligand (7), contained a singlet at $\delta 3.78$ and two doublets $\delta 7.60$ and 6.87 for the $-\mathrm{OCH}_{3}, \mathrm{H}_{2^{\prime}+6^{\prime}}$ and $\mathrm{H}_{3^{\prime}+5^{\prime}}$ protons respectively of the $-\mathrm{C}_{6^{\prime}} \mathrm{H}_{4^{\prime}}\left(\mathrm{OCH}_{3}\right)$ moiety.

Table 2. FTIR spectroscopic data of the compounds as $\mathrm{KBr}$ disc, $v\left(\mathrm{~cm}^{-1}\right)$.

\begin{tabular}{ccccccccc}
\hline Comp. & $\mathfrak{u}(\mathrm{OH})$ & $\mathfrak{u}(\mathrm{N}-\mathrm{H})$ & $\mathfrak{l}(\mathrm{C}=\mathrm{O})$ & $\mathfrak{u}(\mathrm{C}=\mathrm{N})$ & $\mathfrak{l}(\mathrm{C}=\mathrm{C})$ ring & $\mathfrak{l}(\mathrm{C}-\mathrm{O})$ & $\mathfrak{u}(\mathrm{FeN})$ & $\mathfrak{u ( F e O})$ \\
\hline $\mathbf{1}$ & - & $3276 \mathrm{~m}$ & $1647 \mathrm{vs}$ & $1610 \mathrm{~s}$ & $1586 \mathrm{~ms}$ & - & - & - \\
$\mathbf{2}$ & - & $3270 \mathrm{~m}$ & $1642 \mathrm{vs}$ & $1609 \mathrm{~s}$ & $1575 \mathrm{~s}$ & - & - & - \\
$\mathbf{3}$ & - & $326 \mathrm{~m}$ & $1638 \mathrm{~s}$ & $1609 \mathrm{~s}$ & $1576 \mathrm{~m}$ & - & - & - \\
$\mathbf{4}$ & - & $3270 \mathrm{~m}$ & $1645 \mathrm{~s}$ & $1610 \mathrm{~s}$ & $1586 \mathrm{~m}$ & - & - & - \\
$\mathbf{5}$ & - & $3211 \mathrm{~m}$ & $1631 \mathrm{~s}$ & $1609 \mathrm{vs}$ & $1597 \mathrm{~s}$ & - & - & - \\
$\mathbf{6}$ & - & $3246 \mathrm{~m}$ & $1647 \mathrm{vs}$ & $1607 \mathrm{~s}$ & $1541 \mathrm{~m}$ & - & - & - \\
$\mathbf{7}$ & - & $3286 \mathrm{~m}$ & $1649 \mathrm{vs}$ & $1607 \mathrm{~s}$ & $1546 \mathrm{~m}$ & - & - & - \\
$\mathbf{8}$ & $3465 \mathrm{br}$ & - & - & $1607 \mathrm{vs}$ & $1507 \mathrm{~m}$ & $1254 \mathrm{vs}$ & $529 \mathrm{w}$ & $512 \mathrm{w}$ \\
$\mathbf{9}$ & $3421 \mathrm{br}$ & - & - & $1606 \mathrm{~s}$ & $1409 \mathrm{vs}$ & $1254 \mathrm{~s}$ & $533 \mathrm{w}$ & $515 \mathrm{w}$ \\
$\mathbf{1 0}$ & $3449 \mathrm{br}$ & - & - & $1607 \mathrm{~s}$ & $1458 \mathrm{~ms}$ & $1251 \mathrm{vs}$ & $532 \mathrm{w}$ & $485 \mathrm{w}$ \\
$\mathbf{1 1}$ & $3444 \mathrm{br}$ & - & - & $1604 \mathrm{vs}$ & $1557 \mathrm{~s}$ & $1256 \mathrm{~s}$ & $518 \mathrm{w}$ & $495 \mathrm{w}$ \\
$\mathbf{1 2}$ & $3432 \mathrm{br}$ & - & - & $1611 \mathrm{~s}$ & $1587 \mathrm{~s}$ & $1257 \mathrm{~ms}$ & $526 \mathrm{w}$ & $507 \mathrm{w}$ \\
$\mathbf{1 3}$ & $3427 \mathrm{br}$ & - & - & $1609 \mathrm{~s}$ & $1564 \mathrm{~m}$ & $1258 \mathrm{~s}$ & $537 \mathrm{~m}$ & $507 \mathrm{w}$ \\
$\mathbf{1 4}$ & $3463 \mathrm{br}$ & - & - & $1606 \mathrm{vs}$ & $1588 \mathrm{~m}$ & $1264 \mathrm{~m}$ & $536 \mathrm{~m}$ & $495 \mathrm{w}$ \\
\hline
\end{tabular}




\subsection{Magnetic moment and electronic spectra}

The magnetic susceptibility of the complexes was measured at room temperature (300K) using glass magnetic susceptibility tube. The correct mass susceptibility was obtained by deducting the diamagnetic susceptibility of the atoms, ions and constitutive corrections. The observed magnetic moment values are listed in Table 1 . The magnetic moment of complexes (8) and (9) ( $\mu_{\text {eff }} 5.98$ and 5.99 B.M.) are in the range of typical high spin octahedral complexes ( $\mu_{\text {eff }} 5.92$ B.M.), corresponding to five unpaired electrons [18, 21, 22], however the magnetic moment of the other complexes (10-14) 5.44-5.67 B.M lies below the expected ones for high spin Fe(III) complexes [23], suggestive to five coordinated square-pyramidal geometry around the metal center [18]. The electronic spectra of the complexes were recorded on a T60U spectrophotometer using $10^{-5} \mathrm{M}$ solution in DMSO. The absorbance was measured at a slow scan rate at room temperature in a 200-900 $\mathrm{nm}$ range with $0.1 \mathrm{~nm}$ scan resolution. The absorptions are incorporated in Table 4. The ground state of high spin octahedral Fe(III) complexes is ${ }^{6} \mathrm{~A}_{1 \mathrm{~g}}$. The four lowest energy bands are due to the transition from ${ }^{6} \mathrm{~A}_{1 \mathrm{~g}}$ to ${ }^{4} \mathrm{~T}_{1 \mathrm{~g}},{ }^{4} \mathrm{~T}_{2 \mathrm{~g}}$,

Table 3. ${ }^{1} \mathrm{H}-\mathrm{NMR}$ spectroscopic data of the ligands, chemical shift $\delta(\mathrm{ppm})$ in $\mathrm{CDCl}_{3}$.

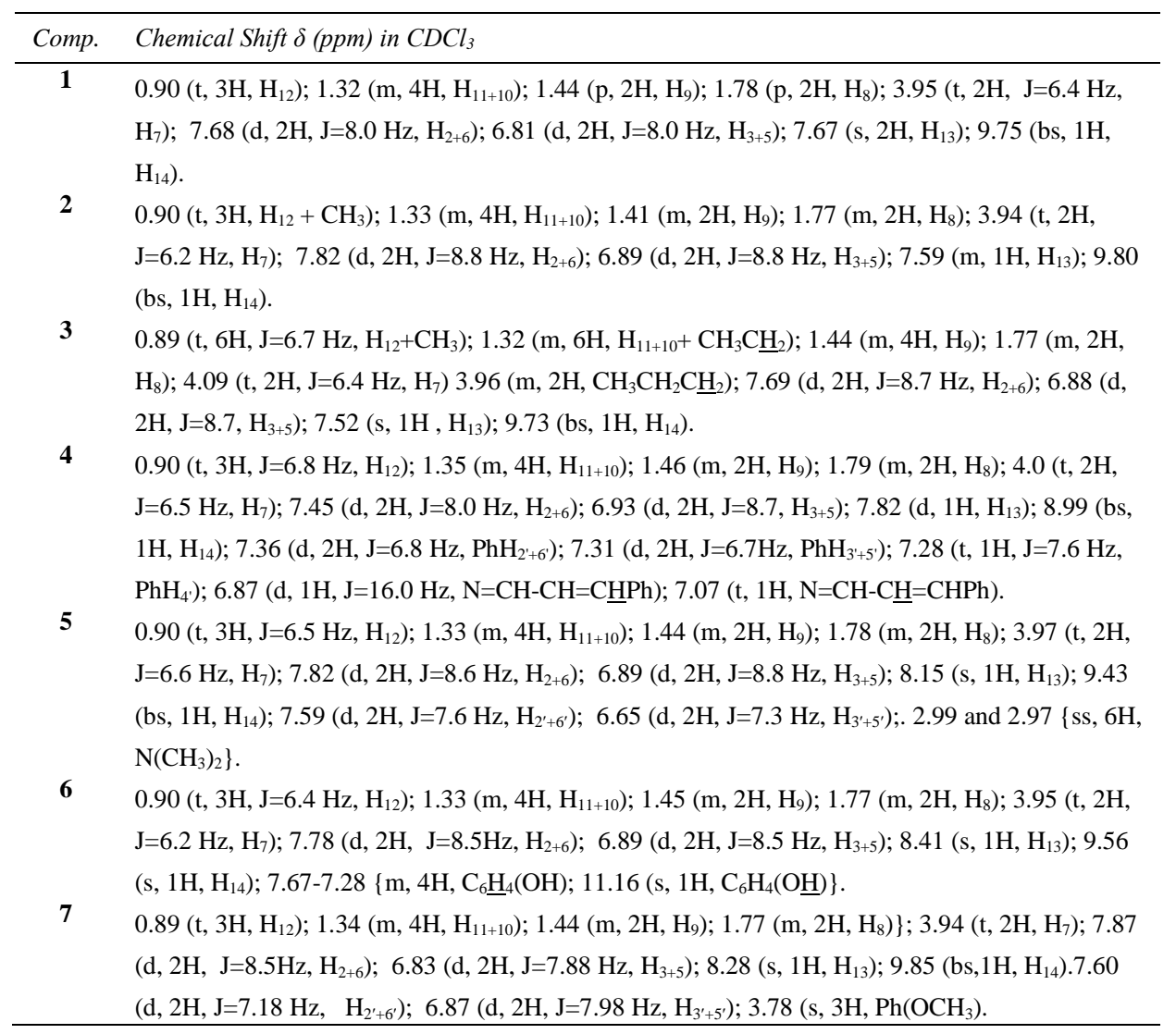


${ }^{4} E_{g}$, and ${ }^{4} A_{1 g}$, excited states. A very sharp band near $400 \mathrm{~nm}$ is due to the transitions to the accidentally degenerate ${ }^{4} \mathrm{~A}_{1 \mathrm{~g}}$ and ${ }^{4} \mathrm{E}_{\mathrm{g}}$ levels. These bands possibly arise from an admixture of spin quartet character to the ground state through spin-orbital coupling. However, this band was not observed in the present study. The complexes (8) and (9) have shown two bands $C a .710$ and $360 \mathrm{~nm}$, may be assigned to the ${ }^{6} \mathrm{~A}_{1 \mathrm{~g}}(\mathrm{~s}) \rightarrow{ }^{4} \mathrm{~T}_{1 \mathrm{~g}}(\mathrm{G})$ and ${ }^{6} \mathrm{~A}_{1 \mathrm{~g}}(\mathrm{~s}) \rightarrow{ }^{4} \mathrm{TE}_{\mathrm{g}}{ }^{4}, \mathrm{~A}_{1 \mathrm{~g}}(\mathrm{G})$ transitions respectively, characteristic of octahedral geometry [24]. On the other hand, five coordinated square-pyramidal Fe(III) complexes exhibit three bands at 1018, 644 and $360 \mathrm{~nm}$ respectively [18, 25, 26], that can be assigned as $d_{x y} \rightarrow d_{x z}, d_{x y} \rightarrow d_{y z}$ and $d_{x y} \rightarrow d_{z}^{2}$. In the present investigation, the complexes (10-14) exhibited a high intensity broad band centered at approximately $360 \mathrm{~nm}$, probably due to the $\mathrm{d}_{\mathrm{xy}} \rightarrow \mathrm{d}_{\mathrm{z}}{ }^{2}$ transition that suggested a square-pyramidal geometry [18]. However, the bands below $300 \mathrm{~nm}$ are consistent with intra ligand charge transfer transitions.

Table 4. Electronic spectral data of the complexes in $\mathrm{DMSO}^{1} \lambda_{\max }(\mathrm{nm})$.

\begin{tabular}{cccc}
\hline Compound & \multicolumn{3}{c}{ Absorption bands, $\lambda_{\max }(\log \varepsilon)$} \\
\hline $\mathbf{8}$ & band - I & band - II & band - III \\
$\mathbf{9}$ & $261(2.76)$ & $331(1.14)$ & $692(0.14)$ \\
$\mathbf{1 0}$ & $290(3.43)$ & $368(2.05)$ & $710(0.30)$ \\
$\mathbf{1 1}$ & $358(9.99)$ & $370(3.48)$ & $710(0.67)$ \\
& $278(5.0)$ & $301(4.13)$ & - \\
$\mathbf{1 2}$ & & $344(3.80)$ & - \\
$\mathbf{1 3}$ & $262(1.72)$ & $341(3.56)$ & - \\
$\mathbf{1 4}$ & & $362(3.53)$ & - \\
\hline
\end{tabular}

${ }^{1}$ Concentration in $10^{-5} \mathrm{~mol} / \mathrm{L}$.

\subsection{Thermogravimetric analyses (TGA)}

The thermal degradation of the complexes (8-14) was studied using TGA technique between room temperature to $600^{\circ} \mathrm{C}$ (Fig. 1), and their successive weight loss are reported in Table 5 . The TGA spectra suggested that the complexes are stable up to 
$100^{\circ} \mathrm{C}$. The data from the thermogravimetric analysis indicated that the decomposition of the complexes was completed in two steps, except that of complex (13), the decomposition was completed in three steps. In the first step, all the complexes lost only their hydrated water molecules [19], within the temperature between $200-238^{\circ} \mathrm{C}$, consistent with the proposed formulae as shown in Table 1 . Since the coordinated water molecule was found to be removed above $300^{\circ} \mathrm{C}$ [20], the complexes under investigation contain no coordinated water molecule. The IR spectra of the complexes also support this assumption. The decomposition was completed between the temperature $580-592^{\circ} \mathrm{C}$ and consequently ferric oxide was formed as residue in the final step. The molecular weight of the complexes was calculated from the percentage of residue and compared with their expected molecular weight. However, the decomposition of complex (13) was completed in three steps, namely at 228,314 and $591^{\circ} \mathrm{C}$. The first step is associated with the loss of two crystal water molecules and the second step is involved with the loss of coordinated chlorine atom.

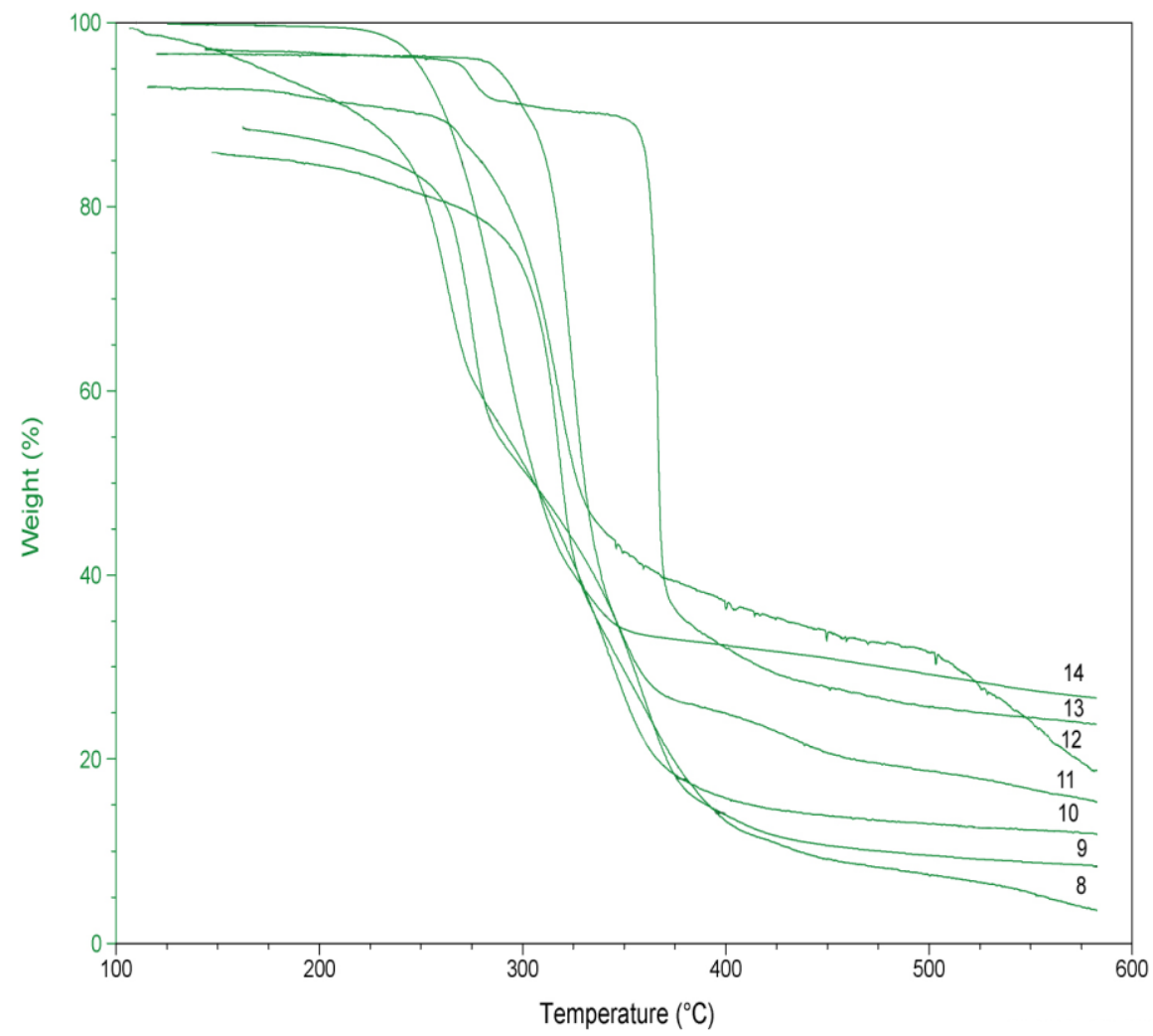

Fig. 1. TGA spectra of the complexes during heating scan at the rate of $10^{\circ} \mathrm{C} / \mathrm{min}$. 
Table 5. Thermogravimetric analyses of the complexes.

\begin{tabular}{|c|c|c|c|c|c|}
\hline $\mathrm{Com}$ & $T\left({ }^{\circ} \mathrm{C}\right)$ & $\begin{array}{c}\text { Wt. loss/resudue (\%) } \\
\text { cal./(found) }\end{array}$ & $\begin{array}{l}\text { Groups lost/ } \\
\text { residue } \\
\text { remained }\end{array}$ & $\begin{array}{l}\text { Proposed } \\
\text { formula }\end{array}$ & $\begin{array}{c}\text { Molecular mass } \\
\text { cal./(found) }\end{array}$ \\
\hline \multirow[t]{2}{*}{8} & 200.48 & 13.65 (13.71) & $7 \mathrm{H}_{2} \mathrm{O}$ & {$\left[\mathrm{Fe}\left(\mathrm{L}_{3}\right)\right] .7 \mathrm{H}_{2} \mathrm{O}$} & 919.35 (923.91) \\
\hline & 591.0 & 17.28 (17.37) & $\mathrm{Fe}_{2} \mathrm{O}_{3}$ (Res.) $)^{2}$ & & \\
\hline \multirow[t]{2}{*}{9} & 264.55 & $9.67(9.81)$ & $5 \mathrm{H}_{2} \mathrm{O}$ & {$\left[\mathrm{Fe}\left(\mathrm{L}_{3}\right)\right] .5 \mathrm{H}_{2} \mathrm{O}$} & 929.96 (928.44) \\
\hline & 587.0 & $17.17(17.20)$ & $\mathrm{Fe}_{2} \mathrm{O}_{3}$ (Res.) $)^{2}$ & & \\
\hline \multirow[t]{2}{*}{11} & 237.57 & $6.40(2.11)$ & $3 \mathrm{H}_{2} \mathrm{O}$ & {$\left[\mathrm{FeL}_{2} \mathrm{Cl}\right] 3 \mathrm{H}_{2} \mathrm{O}$} & 844.24 (841.37) \\
\hline & 582.66 & 18.93 (18.99) & $\mathrm{Fe}_{2} \mathrm{O}_{3}$ (Res.) $)^{2}$ & & \\
\hline \multirow[t]{2}{*}{12} & 205.78 & $6.15(4.56)$ & $3 \mathrm{H}_{2} \mathrm{O}$ & {$\left[\mathrm{FeL}_{2} \mathrm{Cl}\right] 3 \mathrm{H}_{2} \mathrm{O}$} & 878.39 (883.74) \\
\hline & 592.50 & 18.18 (18.07) & $\mathrm{Fe}_{2} \mathrm{O}_{3}$ (Res.) $)^{2}$ & & \\
\hline \multirow[t]{3}{*}{13} & 228.48 & $4.47(5.57)$ & $2 \mathrm{H}_{2} \mathrm{O}$ & {$\left[\mathrm{FeL}_{2} \mathrm{Cl}\right] \cdot 2 \mathrm{H}_{2} \mathrm{O}$} & 806.15 (802.09) \\
\hline & 314.76 & $8.87(8.62)$ & $\mathrm{Cl}+2 \mathrm{H}_{2} \mathrm{O}$ & & \\
\hline & 591.74 & $19.82(19.92)$ & $\mathrm{Fe}_{2} \mathrm{O}_{3}$ (Res.) $)^{2}$ & & \\
\hline \multirow[t]{2}{*}{14} & 238.96 & $2.20(2.36)$ & $\mathrm{H}_{2} \mathrm{O}$ & {$\left[\mathrm{FeL}_{2} \mathrm{Cl}\right] . \mathrm{H}_{2} \mathrm{O}$} & $816.02(815.34)$ \\
\hline & 595.0 & 19.58 (19.59) & $\mathrm{Fe}_{2} \mathrm{O}_{3}$ (Res.) ${ }^{2}$ & & \\
\hline
\end{tabular}

${ }^{2}$ Residue.

\subsection{Antibacterial screening}

The antibacterial sensitivity test of the complexes was studied against sixteen pathogenic bacteria. The test results are depicted as the clear zone of inhibition in diameter (mm) in Table 6. The results indicated that the complexes have shown smaller zone of inhibition than the standard drug (kanamycin), this implies that the complexes are less sensitive to the organisms than the standard drug. Complexes (10) and (13) remain inactive towards the aforesaid bacteria but complexes (8), (9), (11), (12) and (14) showed antibacterial activity. Note that complex (8) showed no activity against $V$. Parahemolyticus and S. Dysenteriae, complex (9) against V. Parahemolyticus, V. Mimicus, S. Aureus, E. Coli, S. Dysenteriae, S. Dysenteriae, P. Aureus, S. Lutea and C. Albicans and complex (11) showed no activity against $S$. Dysenteriae and P. Aureus. The complexes (8), (9), (11), (12) showed resistance against all the bacteria but only complex (14) showed intermediate activity against all the bacteria. The study reveals that electron donating and $\pi$-conjugating substituents at the azomithine moiety increases antibacterial activity of the complexes. 
Table 6. Qualitative antibacterial sensitivity test.

\begin{tabular}{|c|c|c|c|c|c|c|c|c|}
\hline \multirow{3}{*}{ Organism } & \multirow{3}{*}{$\begin{array}{l}\text { Kanamycin } \\
(30 \mu \mathrm{g} / \mathrm{disc})\end{array}$} & \multicolumn{7}{|c|}{ Inhibition zone of compounds (mm) } \\
\hline & & \multicolumn{7}{|c|}{ Compounds $(30 \mu \mathrm{g} / \mathrm{disc})$} \\
\hline & & 8 & 9 & 10 & 11 & 12 & 13 & 14 \\
\hline B. Sereus & 36 & 6 & 7 & 0 & 8 & 8 & 0 & 10 \\
\hline B. Megaterium & 35 & 5 & 7 & 0 & 8 & 8 & 0 & 12 \\
\hline B. Subtilis & 35 & 6 & 7 & 0 & 9 & 9 & 0 & 11 \\
\hline S. Paratyphi & 35 & 6 & 7 & 0 & 7 & 8 & 0 & 12 \\
\hline S. Tiphi & 35 & 7 & 7 & 0 & 7 & 7 & 0 & 11 \\
\hline V. Parahemolyticus & 35 & 0 & 0 & 0 & 7 & 9 & 0 & 10 \\
\hline V. Mimicus & 36 & 9 & 0 & 0 & 8 & 9 & 0 & 10 \\
\hline S. Aureus & 36 & 9 & 0 & 0 & 9 & 8 & 0 & 13 \\
\hline E. Coli & 35 & 9 & 0 & 0 & 9 & 7 & 0 & 11 \\
\hline S. Dysenteriae & 36 & 0 & 0 & 0 & 0 & 8 & 0 & 12 \\
\hline P. Aureus & 35 & 9 & 0 & 0 & 0 & 8 & 0 & 12 \\
\hline S. Lutea & 35 & 9 & 0 & 0 & 8 & 8 & 0 & 10 \\
\hline S. Boydii & 36 & 7 & 9 & 0 & 7 & 8 & 0 & 10 \\
\hline S. Cerevaceae & 35 & 7 & 9 & 0 & 6 & 7 & 0 & 12 \\
\hline C. Albicans & 35 & 7 & 0 & 0 & 7 & 7 & 0 & 12 \\
\hline A. Niger & 35 & 7 & 10 & 0 & 7 & 8 & 0 & 12 \\
\hline
\end{tabular}

\section{Conclusions}

Synthesis and characterization of complexes containing NO-donor bidentate Schiff base ligands have been described in this paper. The spectroscopic data of the complexes suggested good evidence of proposed structure. The investigation suggested that the Schiff's bases coordinated as uninegative bidentate mode through the azomethine nitrogen atom and enolate oxygen anion generated insitu during complexation process. The ligands containing smaller groups at the azomethine moiety formed octahedral geometry, while those with bulky substituent groups generated square pyramidal complexes. The results of the antibacterial screening of the test compounds indicated mild to moderate antibacterial activities.

\section{References}

1. A. Mukherjee, M. A. Cranswick, M. Chakraborti,T. K. Paine, K. Fujisawa, E. Münck, and L. Q. Junior, Inorg Chem. 49, 3618 (2010). http://dx.doi.org/10.1021/ic901891n 
2. C. G. Hamaker, G. A. Mirafzal, and L. K. Woo, Organometallics 20, 5171 (2001). http://dx.doi.org/10.1021/om010513u

3. R. Shukla and P. K. Bharadwaj, Polyhedron 16, 1983 (1993). http://dx.doi.org/10.1016/S0277-5387(00)81470-9

4. S. C. Shoner, D. Barnhart, and J. A. Kovacs, Inorg. Chem. 34, 4517 (1995). http://dx.doi.org/10.1021/ic00122a001

5. T. Beissel, K. S. Bürger, G. Voigt, K. Wieghardt, C. Butzlaff, and A. X. Trautwein, Inorg. Chem. 32, 124 (1993). http://dx.doi.org/10.1021/ic00054a002

6. N. Govindaswamy, D. A. J. Quarless, and S. A. Koch, J. Am. Chem. Soc. 117, 8468 (1995). http://dx.doi.org/10.1021/ja00137a024

7. P. V. Bernhardt, P. Chin, P. C. Sharpe, J.-Y. C. Wang, and D. R. Richardson, J. Biol. Inorg. Chem. 10, 761 (2005). http://dx.doi.org/10.1007/s00775-005-0018-0

8. L. N. Suvarapu, Y. K. Seo, S. O. Baek, and V. R. Ammireddy, E-J. Chem. 9, 1288 (2012)

9. W. L. F. Armarego and L. L. C. Christina, Purification of Laboratory Chemicals (Elsevier Butterworth Heinemann, Great Britain, 2003).

10. M. B. H. Howlader, M. T. H. Tarafder, and M. A. A. A. A. Islam, Ind. J. Chem. 48A, 1078 (2009).

11. M. A. A. A. A. Islam, M. A. Mumit, M. A. Alam, A. Chowdhury, and M. C. Sheikh, Asian J. Chem. 23, 1075 (2011).

12. T. K. Pal, M. A. Alam, M. A. A. A. A. Islam, and S. R. Paul, J. Sci. Res. 4, 427 (2012). doi: http://dx.doi.org/ 10.3329/ jsr.v 4i2.9366

13. M. B. H. Howlader and M. S. Begum, Indian J. Chem. 43A, 2352 (2004).

14. W. J. Geary, Coord. Chem. Rev. 71, 81 (1971). http://dx.doi.org/10.1016/S00108545(00)80009-0

15. T. K. Pal and M. A. Alam, J. Sci. Res. 1, 647 (2009). http://dx.doi.org/10.3329/jsr.v1i3.2259

16. P. B. Chatterjee, D. Mandal, A. Audhya, K. Y. Choi, A. Endo, and M. Chaudhary, Inorg. Chem. 47, 3709 (2008). http://dx.doi.org/10.1021/ic702286h

17. M. V. Girgaonkar, and S. G. Shirodkar, J. Chem. Pharm. Res. 4, 260 (2012).

18. D. Singh, and K. Kumar, J. Serb. Chem. Soc. 75, 475 (2010). http://dx.doi.org/10.2998/JSC091021028S

19. M. B. H. Howlader, M. M. Khatun, and M. B. Hossain, J. Bang. Chem. Soc. 16, 94 (2003).

20. M. S. Refat, I. M. Al-Deen, H. K. Ibrahim, and S. El-Ghool, Spectrochim. Acta Part A. 65, 1208 (2006). http://dx.doi.org/10.1016/j.saa.2006.01.049

21. D. P. Singh, K Kumar, and C. Sharma, Eur. J. Med. Chem. 44, 3299 (2009). http://dx.doi.org/10.1016/j.ejmech.2009.02.029

22. R. Chaudhary and Shelly, J. Chem. Pharm. Res. 2, 707 (2010).

23. P. Kopel, M. Biler, Z. Trávníèek, and M. Nádvorník, Chemica. 37, 17 (1998).

24. M. Revanasiddappa, T. Suresh, S. Khasim, S. C. Raghavendra, C. Basavaraja, and S. D. Angadi, E-J. Chem. 5, 395 (2008).

25. D. P. Singh and R. Kumar, J. Serb. Chem. Soc. 72, 1069 (2007). http://dx.doi.org/10.2298/JSC0711069S

26. A. B. P. Lever, Inorganic Electronic Spectroscopy (Elsevier, Amsterdam, 1984). 